大学男女アスリートにおける上気道感染症の発症状況と 1 週間の運動時間

砂見 綾香 ${ }^{1,2}$, 佐々木 和登 ${ }^{1}$ 江崎 治 $^{3}$, 中井あゆみ ${ }^{1}$, 安田 純 $^{1}$, 横山 友里 ${ }^{1,2}$, 吉㠃 貴大 ${ }^{4}$, 多田 由紀 ${ }^{5}$, 日田 安寿美 ${ }^{5}$, 川野 因 ${ }^{5}$

\title{
Incidence of upper respiratory tract infection and duration of weekly training among Japanese collegiate male and female athlete
}

\author{
Ayaka Sunami ${ }^{1,2}$, Kazuto Sasaki ${ }^{1}$, Osamu Ezaki ${ }^{3}$, Ayumi Nakai ${ }^{1}$, Jun Yasuda ${ }^{1}$, Yuri Yokoyama ${ }^{1,2}$, \\ Takahiro Yoshizaki $^{4}$, Yuki Tada ${ }^{5}$, Azumi Hida ${ }^{5}$ and Yukari Kawano ${ }^{5}$ \\ ${ }^{1}$ 東京農業大学大学院農学研究科食品栄養学専攻, ₹ 156-8502 東京都世田谷区桜丘 1-1-1 (Department of Food and Nutrition- \\ al Science, Graduated School of Tokyo University of Agriculture, 1-1-1 Sakuragaoka, Setagaya-ku, Tokyo 156-8502, Japan) \\ ${ }^{2}$ 日本学術振興会，７102-0083 東京都千代田区麹町 5-3-1 (Japan Society for the Promotion of Science, 5-3-1 Koujimachi, \\ Chiyoda-ku, Tokyo 102-0083, Japan) \\ 3 昭和女子大学生活科学部健康デザイン学科, テ 154-8533 東京都世田谷区太子堂 1-7-57 (Department of Healthcare Design, \\ Showa Women's University, 1-7-57 Taishido, Setagaya-ku, Tokyo 154-8533, Japan) \\ ${ }^{4}$ 東洋大学食環境科学部, ₹374-0193 群馬県邑楽郡板倉町泉野 1-1-1 (Department of Nutritional Science, Toyo University, \\ 1-1-1 Izumino, Itakura-machi, Oura-gun, Gunma 374-0193, Japan) \\ 5 東京農業大学応用生物科学部栄養科学科, ₹ 156-8502 東京都世田谷区兴丘1-1-1 (Faculty of Food and Nutritional Sci- \\ ence, Tokyo University of Agriculture, 1-1-1 Sakuragaoka, Setagaya-ku, Tokyo 156-8502, Japan)
}

Received: August 24, 2015 / Accepted: October 14, 2015

\begin{abstract}
Strenuous exercise induces upper respiratory tract infection (URTI), whereas moderate exercise prevents URTI. This study aimed to assess the incidence of URTI and the association between URTI episodes and exercise duration in Japanese collegiate athletes. A cross-sectional survey was conducted with 1,740 participants; 1,235 responses were eligible for analysis. Participants were classified into three groups: control group (weekly total exercise duration $<60$ min, $\mathrm{n}=405$ ), exercise group (weekly total exercise duration $>60$ min, $\mathrm{n}=193$ ), and athlete group (joined a sports club and weekly exercise frequency $>5$ days, $n=637$ ). We requested the following information from participants: basic characteristics, incidence of URTI symptoms (fever, runny or plugged nose, sore throat, and cough) or influenza for each month over the past year, day of the week exercise is typically performed, and duration of exercise per week. The incidence of URTI episodes per year was significantly lower in the athlete group (2.0 \pm 2.4 episodes $)$ compared to the control group $(2.6 \pm 2.4$ episodes, $\mathrm{p}<0.001)$. The incidence of URTI episodes did not significantly differ between the control group and exercise group (2.9 \pm 2.9 episodes, $\mathrm{p}=0.607$ ). Although the frequency of URTI episodes and exercise duration were not significantly associated among male athletes $(\mathrm{p}=0.209)$, they were positively associated in female athletes $(\mathrm{p}=0.027)$. These results indicate that Japanese collegiate athletes experience fewer URTI episodes than non-athletes, but athletes who exercise for long durations may frequently experience URTI, particularly female athletes.
\end{abstract}

Jpn J Phys Fitness Sports Med, 65(1): 189-196 (2016)

Keywords : sports, illness, URTI, exercise duration

\author{
緒 言 \\ アスリートは，試合で勝つことを目指して日々トレー \\ ニングを行っている。しかし, 適度な運動習慣をもつ者 \\ は上気道感染症（Upper Respiratory Tract Infection, \\ URTI）の発症数が少ないのに対して, 高強度運動を行 \\ うアスリートでは多いことが報告されている1,2). 水泳選
}

手では，試合前 6 週間にURTIなどの体調不良を訴えた 者はパフォーマンスが低下し ${ }^{3)}$ ，エリート長距離選手で も，体調不良日が多い年ほど 1 年間のトレーニング時間 が短いと報告されている ${ }^{3)}$ 。これらの結果から, アスリー トが試合で最高のパフォーマンスを発揮するためには, 日頃から十分なトレーニングをこなし，試合前の体調を 万全に整えることが重要である。しかし, 日本人大学生 
アスリートのURTI発症の実態は必ずしも十分に明らか にされていないことから，URTIが発症しやすい時期を 明らかにすることは, 予防の観点からも重要になる.

そこで本研究では，体育系部活動所属者を含めた日本 人男女大学生を対象に直近 1 年間のURTI発症状況を運 動習慣別に比較するとともに，大学生アスリートにおい て一週間あたりの運動時間とURTI発症数との関連を明 らかにすることを目的とした。

\section{方法}

対象 関東または中部地方にある 7 大学に所属する大学 生・大学院生を対象とした。研究開始前に研究の目的, 方法を口頭により十分説明し，調査票への回答执よび提 出を以て研究対象者として同意したと判断する旨を伝え た。なお，調査票への回答は無記名として匿名性を保ち， 本人への不利益が生じないことを説明した。本研究は東 京農業大学倫理審査委員会（承認番号; 1125）の承認を 得て実施した。

調査手順および調査内容 2013 年 7 月から 10 月の約 3 カ月間に調查票を配布して自記式で回答を得た。調查 項目は，性別，年齢，学年，身長，体重，平均的な 1 週 間あたりの運動日数，運動日の平均的な運動実施時間， 体育系部活動への所属の有無掞よび競技種目，URTIの 発症状況とした。なお，対象者の所属する体育系部活動 は, 陸上競技 (短距離, 中距離, 長距離, 投擲, 跳躍), サッ カー, テニス, 水球, アーチェリー, バドミントン, 八 ンドボール，ラグビー，スピードスケート，フェンシン グ, 野球, 水泳飛び达み, 剣道, 空手道, レスリング, 体操, 水泳, ダンス, 柔道, なぎなた, バスケットボール, 少林寺拳法, 相撲, 合気道, ラクロス, 社交ダンス, バ レーボール, スキー, ソフトボール, チアリーディング, ライフセービング，アルペンスキー，体操，新体操，競 技ダンス，アルティメットであった。自己申告で回答さ れた身長，体重から「体重 $(\mathrm{kg}) \div$ 身長 $(\mathrm{m})^{2} 」$ の式より Body Mass Index（BMI）を計算し， 1 週間あたりの運 動時間は「1 週間あたりの運動日数」と「運動日の運動 時間」を乗じて計算した。URTIについては,「風邪発 症状況について，最近 1 年間で，発熱，鼻水·鼻づまり， のどの痛み，咳の症状がそれぞれ 2 日以上（14日未満） 続いた月や，インフルエンザと診断された月はありまし たか？」という質問を行い4.5)，直近 1 年間（1月から 12月まで）の月ごとの発症状況について回答を求めた。 すなわち，上記 5 項目のうち 1 つ以上の症状があった場 合に「当該月のURTIは有り」と定義した。思い出し調査 は授業あるいはミーティングの前後に行い，回答時には 複数の調査員が巡回した。回答時の思い出しに信頼性を 持たせる工夫として, 手帳などをみて年間行事を確認し，
さらに行事などの様子を思い出して友人同士で当時の様 子を確認させた，その際，アレルギー反応と思われる 14 日間以上にわたる継続的な症状がみられる場合 ${ }^{6)}$ は，本 研究で対象とする症状ではない旨を十分に説明し，注意 して回答するよう指示をした。月ごとのURTIの有無か ら URTI発症月を合計して年間URTI発症数とした。

統計解析 調查票配布から解析対象者確定までの流れを Fig. 1に示した。調查票は1740名に配布し，1692名か ら回収した。本研究では大学生の直近 1 年間のURTI発 症状況を調査することを目的としたため, 回答時に大学 1 年生だった 206 名を解析対象から除外した。また，調 査項目に記入漏れがある学生 169 名を解析対象から除外 した。ささらに，対象者を日頃の運動習慣をもとに 3 群に 分類した。すなわち, 体育系部活動に所属しておらず 1 週間あたりの合計運動時間が 60 分未満7)の学生 405 名を 運動習慣のない一般大学生（以下, Control群), 体育系 部活動に所属せず 1 週間あたりの合計運動時間が 60 分 以上の学生 193 名を運動習慣のある一般大学生（以下,

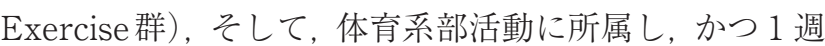
間あたりの運動日数が 5 日以上の学生 637 名を大学生ア スリート（以下，Athlete群）とした。体育系サークル・ 同好会に所属している学生は週あたりの運動時間から Control群あるいはExercise 群に分類した。体育系部活 動に所属しているものの運動日数が週 5 日未満の学生 82 名は解析から除外した。最終的に, 計 1235 名を解析対象 とした

統計解析では，2 群間の比較にMann-WhitneyのU 検定を用いた，運動習慣の違いによる 3 群間の比較に はKruskal-Wallis 検定を行い，有意差がみられた場合 はControl群を基準として Bonferroni法による多重比較 を行った。また，Athlete群については，1 週間あたり の運動時間をもとに 3 分位に分けて運動時間とURTI発 症数の関連を検討した，傾向性の検定にはJonckheereTerpstra検定を用いた。ささらに，第 1 三分位に対する URTI発症リスクを検討するため, ロジスティック回㷌 分析を行ってオッズ比抢よび95\%信頼区間を算出した。 解析ソフトはIBM SPSS Statistics ver.22を用い, 有意水 準は $5 \%$ とした，值はすべて平均值士標準偏差あるいは 人数（\%）で示した。

\section{結果}

運動習慣の異なる大学生におけるURTI発症数および発 症者割合の比較 対象者特性拧よび 1 年間の URTI発症 数を Table 1に示した，対象者のうち，男性は498名，女 性は737名であった。男性割合はExercise群，Athlete 群がControl群に比べて有意に多く, 男女とも, 体重, BMI，運動時間はControl群に比べてExercise 群，Ath- 


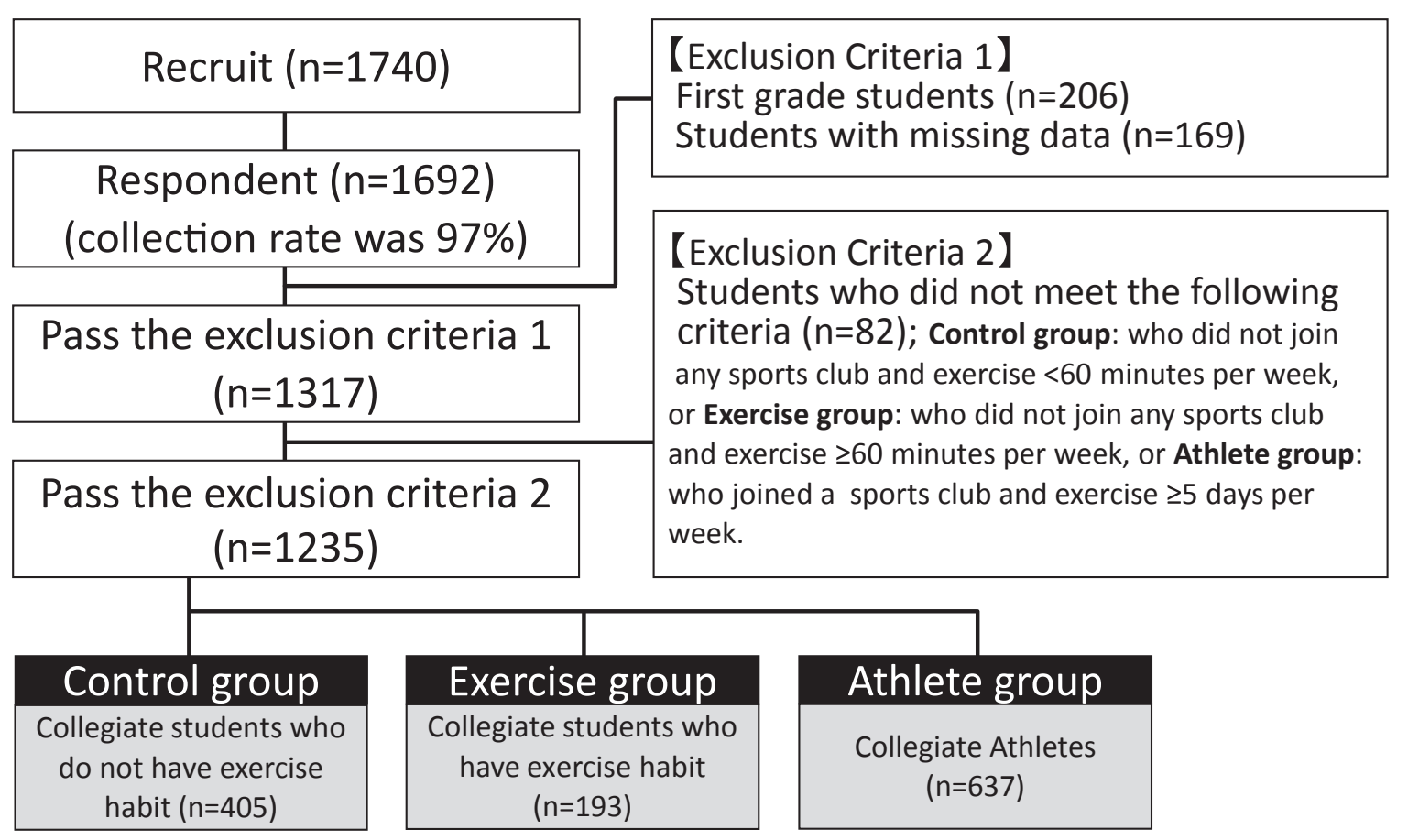

Fig. 1 Study flow chart: screening and enrollment of study participants.

Control group is as person who exercise $<60 \mathrm{~min}$ per week, Exercise group is as person who exercise $\geq 60 \mathrm{~min}$ per week, and Athlete group is as person who join sports club and exercise $\geq 5$ days per week.

lete群が有意な高值を示した。 1 年間のURTI発症数は, 男性，女性のいずれもControl群とExercise群の間に有 意差はみられなかったが, Control群に比べてAthlete群 が有意な低值を示した。また，インフルエンザ発症数は 男女いずれの 3 群間にも有意差はみられず, 1 年間の平 均発症回数は 0.1 回であった。

URTI発症者割合の月間推移を Fig. 2 に示した. URTI 発症者割合は, Control群, Exercise群, Athlete群でほ ほ同様に推移しており, 発症者は夏に少なく, 冬から春 にかけて増加し，5月が最も多かった。ただし, Athlete 群の罹患率は最も少なかった。男性のControl群および Athlete群では 2 月にもピークがみられたのに対し, 女 性のControl群, Exercise群では12月と 1 月にもピーク が観察された。女性のAthlete群では 5 月にピークが観 察されたのみであった. Athlete群のURTI出現率は, 7 月を除き男女間で有意差はみられなかった。

大学生アスリートにおける 1 週間あたりの運動時間と URTI発症数との関連 1 週間あたりの運動時間をもと にAthelte群を三分位に分け, URTI発症数との関連を検 討した（Table 2)，男性では，運動時間と各症状の発症 数との間に有意な関連はみられなかった。しかし，女性 では運動時間が長い者ほど総URTIおよび鼻水・鼻づま り症状の発症数が有意に多かった。

さらに, Table 1よりAthlete群の年間URTI発症数が
平均 2.0 回だったことから，運動時間と年間URTI発症 数が平均 3.0 回以上になるリスクを検討した。その結果, 男性では有意な関連がみられなかったが，女性では 1 分 位数上がるごとに年間URTI発症数が 3.0 回以上となる オッズ比が1.44（95\%信頼区間, 1.08-1.91）となり，有 意な正の関連がみられた。特に，第 1 三分位を比較基準 とすると，第 2 三分位のオッズ比は 1.21 (95\%信頼区間 0.66-2.23)，第 3 三分位のオッズ比は2.03（95\% 信頼区間 は1.15-3.58）であった。

\section{考察}

本研究では, 日本人大学生男女を対象に，（1）年間を 通したURTI発症状況を運動習慣別に把握すること，ま た（2）大学生アスリートにおいて 1 週間あたりの運 動時間と年間URTI発症数との関連を明らかにすること を目的とした。その結果，男女ともにAthelte群の年間 URTI発症数は, Control群に比べて有意に少なく, 男性 では運動時間とURTI発症数との間に有意な関連はみら れなかった。一方, 女性においては運動時間の増加と URTI発症数の増加に有意な関連が認められた。

身体活動量とURTI発症リスクとの間にはJカーブ型 の関連があり ${ }^{8)}$ ，エリートアスリート（運動量が20-30 $\mathrm{MET} \cdot \mathrm{h} /$ 日程度）は運動習慣のない一般人よりも URTI 発症数が多く, レクリエーションアスリート（運動量が 5-10 MET・h/日程度）は運動習慣のない一般人よりも 


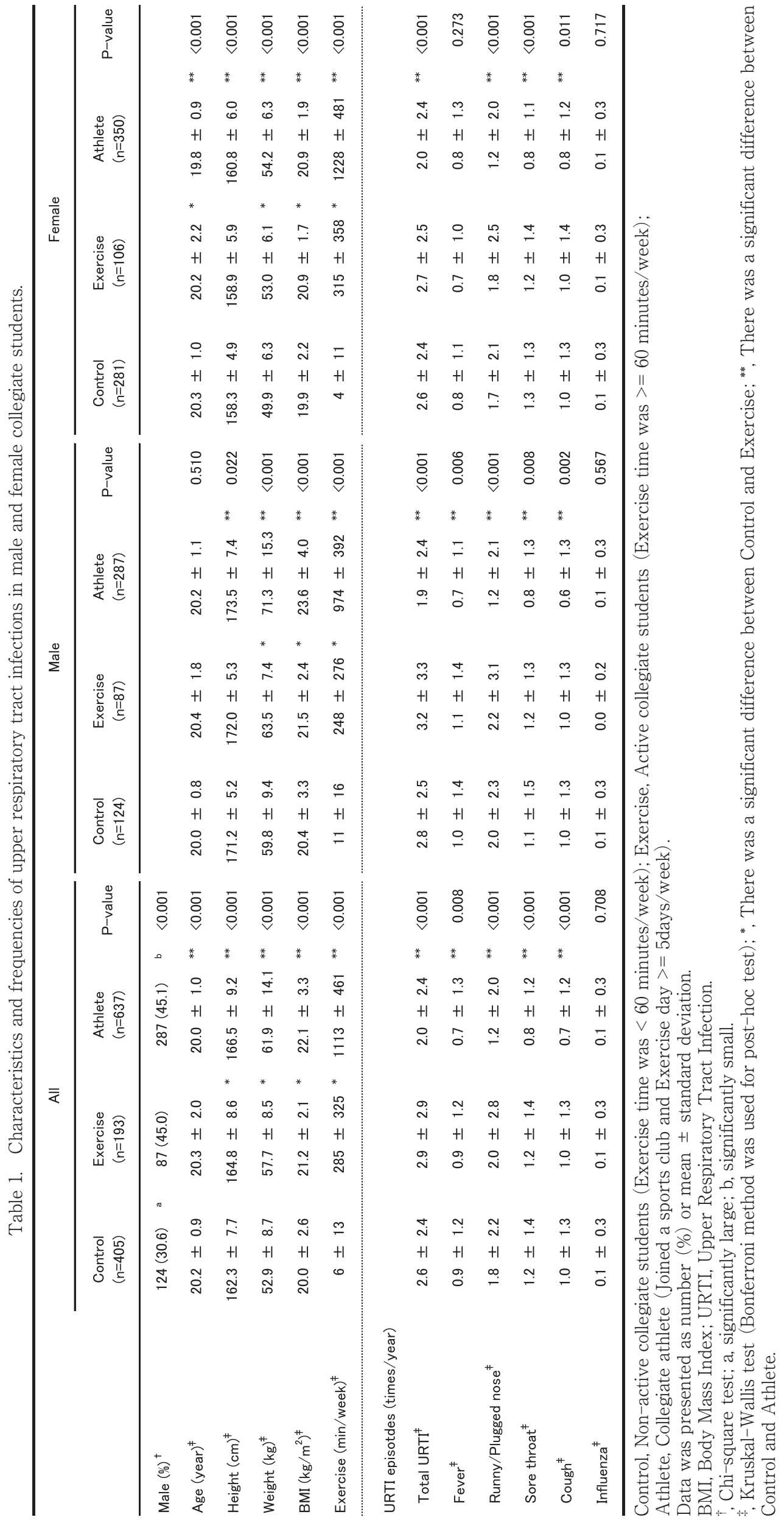




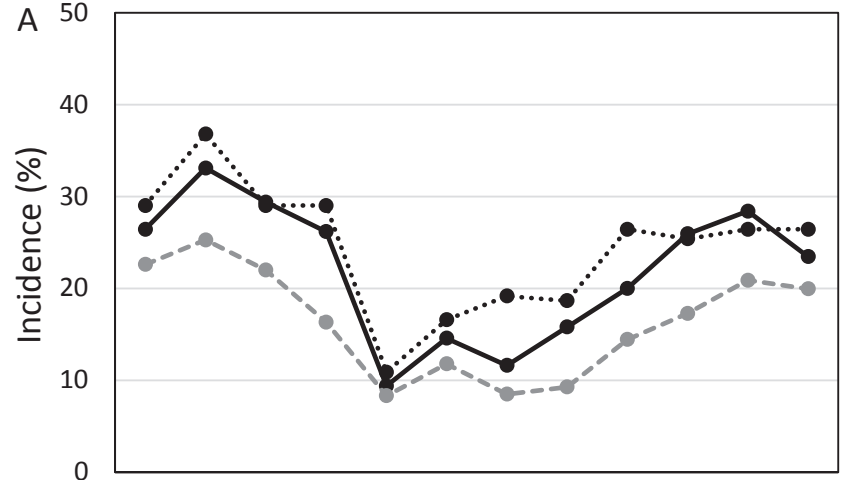

Apr. May Jun. Jul. Aug. Sep. Oct. Nov. Dec. Jan. Feb. Mar.

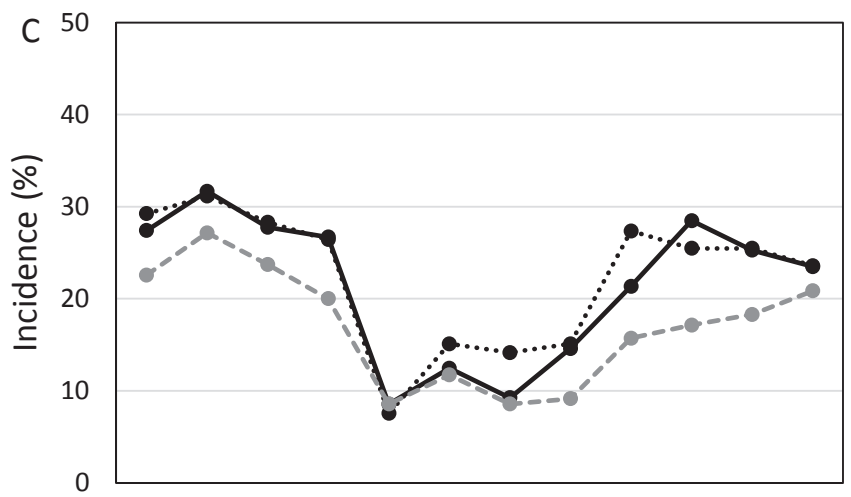

Apr. May Jun. Jul. Aug. Sep. Oct. Nov. Dec. Jan. Feb. Mar.

少ないことが報告されている11，さらに，URTIを発症 したエリートアスリートの直近 1 週間の運動時間は 22.4 \pm 5.8 時間とも報告されている ${ }^{9)}$. 一方，一般成人を対象 とした研究では, 身体活動量（いわゆる運動および日常 生活活動も含めた活動量）が高い者（55 MET・h/日以 上）は低い者 $(45 \mathrm{MET} \cdot \mathrm{h} /$ 日未満) よりURTI発症リ スクが低く ${ }^{5)} ， 3$ Mets 以上の中・高強度の運動に限定し ても，1日あたり 6-7 MET・h以上の運動をする者は運 動習慣のない者に比べてURTI発症リスクが20\%ほど低 かった ${ }^{2)}$. 本研究では運動量を評価することができなかっ たが，Niemanの報告によれば，週あたりの走行距離が 長いほどURTI発症リスクが増加することを報告してお $り^{8)}$ ，加えて，複数の競技種目のアスリートを対象とし た調査では，週あたりの運動時間が 1 時間延びるにつれ てURTI発症リスクが1.05倍ずつあがることが報告され ている ${ }^{10)}$ ，運動量 $(\mathrm{MET} \cdot \mathrm{h})$ がMets と運動時間の積 から得られることを考えると，一定量の運動を行ってい るアスリートに抢いては，運動時間も上気道感染症のリ スク因子の1つであると考えられる。しかし，本研究の 男子大学生アスリートは，1週間あたりの運動時間が平 均 16 時間であり, URTIを発症したエリートアスリート の運動時間 ${ }^{9)}$ よりも少なかった。このことから, 本研究 に扔ける男子大学生アスリートの運動量は, URTI発症

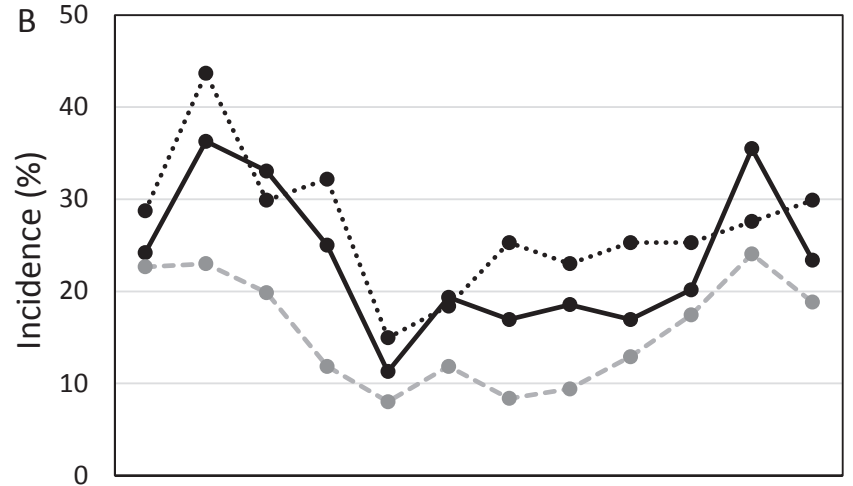

Apr. May Jun. Jul. Aug. Sep. Oct. Nov. Dec. Jan. Feb. Mar.

Fig. 2 Seasonal variation of URTI incidence.

A; All participants $(n=1235)$, B; Males $(n=498)$, C; Females $(\mathrm{n}=737)$

Control group, "........ Exercise group,

$=-1-=$ Athlete group.

Control group is as person who exercise $<60$ min per week, Exercise group is as person who exercise $\geq 60$ min per week, and Athlete group is as person who join sports club and exercise $\geq 5$ days per week.

数の少ないレクリエーションアスリートの運動量と同程 度であったと考えられる。すなわち，発症リスクの最 も少ない運動量（ J カーブの底）であった可能性が高 い. 一方，女性アスリートでは 1 週間あたりの運動時間 とURTI発症数との間には正の関連がみられ，さらに， URTI発症リスクが有意に高かった第 3 三分位の運動時 間の中央值は 1 週間あたり約 25 時間であった。このこ

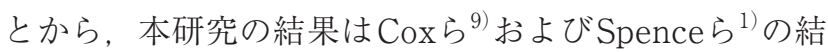
果と一致することが示された，それゆえ，女性では運動 時間が 1 週間に 25 時間を超える場合は，URTI発症に関 する注意喚起が必要であることが明らかになった，大学 生は生活面および経済面において親から独立する世代で あるが，望ましい食習慣や運動習慣など，健康状態を自 己管理する能力が低いと報告されている11,12)，特に，一 人暮らしの大学生では朝食欠食率が高く ${ }^{13)}$, 不規則な夜 型生活や不十分な栄養素等の摂取状況などから，体調不 良を訴える者が多かった ${ }^{14)}$ 。このことから，生活習慣・ 食習慣の乱れている大学生アスリートはURTIを発症し やすい可能性があると考えられる，今後は，大学生アス リートのURTI発症状況と生活習慣, 食習慣との関わり を検討し，新たな予防策を検討・立案する必要があると 考える。

Matthewsら ${ }^{2)}$ は，アメリカ人成人のURTI発症状況を 


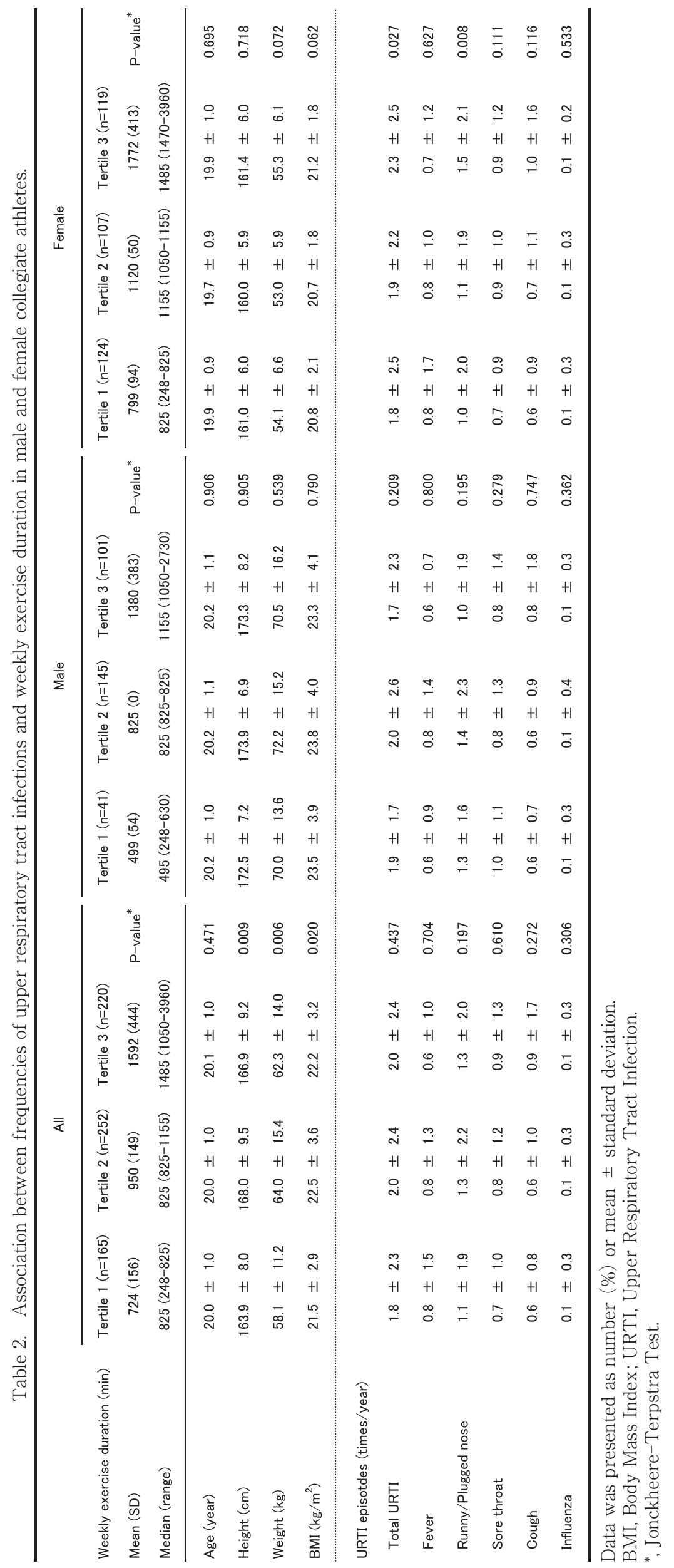


1 年間にわたって調査し, 夏の 8 月が最も少なく, 冬か ら春先の 12 月から 3 月に発症数が多いことを報告して いる. 本研究に扔いても，8月の発症数が最も少なく, 冬に近づくにつれて増加した。 この時, Athlete群と Control群のURTI発症者割合の推移を比べると大きな 違いはみられなかった。このことから, 日本人大学生ア スリートの場合, 平均URTI発症数は一般大学生に比べ て少ないものの, 一般的な流行に沿って感染を原因とし たURTIが発症している可能性が考えられた ${ }^{1,9)}$ ．水泳選 手では試合前 6 週間にURTIなどによる体調不良を訴え た者はパフォーマンスが悪く15)，マラソン選手でもレー ス 3 週間前にURTIを発症した者はマラソンレース後の URTI再発リスクが 2.3 倍に増えたことが報告されてい $る^{16)}$ 。これらの報告は, 試合前にURTIを発症することは, 当該の試合時だけでなく次の試合にも影響を与える可能 性を示している。また，アスリートでは運動量の増加が URTI症状の増加に関わることが報告されている ${ }^{17)}$ 。こ れらのことから，冬季や春季にシーズンを迎える競技種 目や基礎体力の強化を目的に運動量を増加させる競技種 目は, ウイルスの一般的な流行に加えて上気道感染症に かかりやすくなる可能性があり, 競技成績が悪くなる可 能性や，トレーニング計画に悪影響がでる可能性が高い と考えられる.よって，今回の結果から，日本では特に 冬季から春季のURTI発症予防が競技力向上のために重 要であると考えられた。 なお, 本研究では女性Athlete 群は男性Athlete群に比べて 7 月にURTI発症率が有意 に高かった，女性Athlete群の競技者割合は陸上競技が 最も多く, 次いで新体操などを含む体操・ダンスであり, 男性Athlete群はサッカーや柔道, 剣道が多かった。 今 後は，年間トレーニング計画を含めた競技種目がURTI 出現に関わる可能性についても検討する必要がある.

本研究にはいくつかの限界がある。一つ目に, URTI の発症状況調査は過去 1 年間の思い出しで実施したた め, 発症数が過小評価された可能性がある。しかし, 高 齢者に打いては, 過去 1 年間の思い出し調査から得られ た平均発症数は 1 年間の追跡調查から得られた平均発症 数とほぼ同值であったことが報告されている ${ }^{18)}$.さらに, 20-24歳男女の URTI発症数は年間約 3 回と報告されて いる ${ }^{19)}$ 。また, ドイッ人アスリートの年間 URTI発症数 は 0 回が $27.9 \% ， 1-2$ 回が $52.7 \% ， 3$ 回以上が $19.4 \%$ と されている ${ }^{10)}$. 本研究の結果でも, 1 年間のURTI発症 数は 0 回が $27.6 \%, 1-2$ 回が $45.5 \%, 3$ 回以上が $26.8 \%$ で あり, 先行研究の結果とほほ一致した。このことから, 本研究で得られたURTI発症数が過度に過小評価された 可能性は小さいと考えられた。しかし, 回答時の環境や 性差, 競技種目の違いが回答傾向にどのような影響を与 えたかは不明である。このことから, 今後は 1 年間の追 跡調査を行い, より詳細に発症時期を明らかにしていく
必要があると考える。二つ目に，運動強度を考慮してい ないため, 運動時間とURTI発症数の関連を過小あるい は過大評価した可能性がある。ささらに，期分けを考慮し ていないため, URTI発症者割合の月間推移のピークが

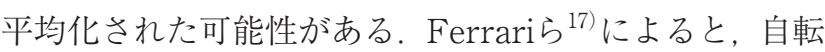
車選手では試合期よりも準備期でURTI症状の合計得点 が高く, 運動時間と運動強度で評価したトレーニング量 と有意な正の関連を示すことが報告されている。このこ とから，今後は練習記録や活動量計を用いて身体活動量 や運動量（MET・h）を把握し, 生活習慣による身体活 動量の違いや競技種目による運動量の違い，期分けによ る運動量の変化を考慮したさらなる研究が必要である. しかし本研究は, 一般大学生に加えて多様な競技種目の 大学生アスリートを包括的に調查し, 運動習慣別に 1 年間のURTI発症状況を調査した点, さらに大学生アス リートに扔ける年間URTI発症数に 1 週間あたりの運動 時間が関わる可能性を示した点に本研究の意義があると 考える。

\section{結 語}

日本の男女大学生はアスリートを含め, 8 月の夏季に URTI発症数が最も少なく, 12 月から 1 月の冬季に増加 し，初夏の 5 月にピーク值を示した。 そして，アスリー 卜群は一般大学生に比べてURTIを発症しにくいもの の，とくに女性アスリートでは，1 週間あたりの運動時 間が 25 時間以上の場合に年間URTI発症数が増える可能 性が明らかとなった。このことから，季節では冬から初 夏にかけて，さらに女性アスリートでは運動時間が多い 者について, URTI発症予防のために生活習慣や食習慣 から予防策を提示する必要があると考えられた。

利益相反自己申告：申告すべきものはなし

\section{謝 辞}

本研究の実施にご協力いただきました有賀誠司先生（東 海大学), 岡田早苗先生 (東京農業大学), 古泉佳代先生 (日 本女子体育大学), 小久保友貴先生 (金城学院大学), 鈴木良 雄先生 (順天堂大学), 須永美歌子先生 (日本体育大学), 新 村洋一先生（東京農業大学）に心から打礼申し上げます。 本研究は日本学術振興会特別研究員奨励費 (No. 13J09447) を受けて実施致しました。

\section{文献}

1) Spence L, Brown WJ, Pyne DB, Nissen MD, Sloots TP, McCormack JG, Locke AS, Fricker PA. Incidence, etiology, and symptomatology of upper respiratory illness in elite athletes. Med Sci Sports Exerc 39: 577586, 2007.

2) Matthews CE, Ockene IS, Freedson PS, Rosal MC, Merriam PA, Hebert JR. Moderate to vigorous physi- 
cal activity and risk of upper-respiratory tract infection. Med Sci Sports Exerc 34: 1242-1248, 2002.

3) Martensson S, Nordebo K, Malm C. High Training Volumes are Associated with a Low Number of SelfReported Sick Days in Elite Endurance Athletes. J Sports Sci Med 13: 929-933, 2014.

4) Li L, Werler MM. Fruit and vegetable intake and risk of upper respiratory tract infection in pregnant women. Public Health Nutr 13: 276-282, 2010.

5) Fondell E, Lagerros YT, Sundberg CJ, Lekander M, Balter O, Rothman KJ, Balter K. Physical activity, stress, and self-reported upper respiratory tract infection. Med Sci Sports Exerc 43: 272-279, 2011.

6) Shinkai S, Toba M, Saito T, Sato I, Tsubouchi M, Taira $\mathrm{K}$, Kakumoto K, Inamatsu T, Yoshida H, Fujiwara Y, Fukaya T, Matsumoto T, Tateda K, Yamaguchi K, Kohda N, Kohno S. Immunoprotective effects of oral intake of heat-killed Lactobacillus pentosus strain b240 in elderly adults: a randomised, double-blind, placebocontrolled trial. Br J Nutr 109: 1856-1865, 2013.

7）厚生労働省. 健康づくりのための身体活動基準 2013. http://www.mhlw.go.jp/stf/seisakunitsuite/bunya/ kenkou_iryou/kenkou/undou/index.html.

8) Nieman DC. Exercise, upper respiratory tract infection, and the immune system. Med Sci Sports Exerc 26: 128-139, 1994.

9) Cox AJ, Gleeson M, Pyne DB, Callister R, Hopkins WG, Fricker PA. Clinical and laboratory evaluation of upper respiratory symptoms in elite athletes. Clin $J$ Sport Med 18: 438-445, 2008.

10) Konig D, Grathwohl D, Weinstock C, Northoff H, Berg A. Upper respiratory tract infection in athletes: influence of lifestyle, type of sport, training effort, and immunostimulant intake. Exerc Immunol Rev 6: 102-120,
2000.

11) Strong KA, Parks SL, Anderson E, Winett R, Davy BM. Weight gain prevention: identifying theory-based targets for health behavior change in young adults. $J$ Am Diet Assoc 108: 1708-1715, 2008.

12）藤塚千秋, 藤原有子, 石田博也, 米谷正造, 木村一彦 : 大 学新入生の生活習慣に関する研究, 川崎医療福祉学会 誌, 12: 321-330, 2002.

13）西尾恵里子, 太田成俊, 田中雄二 : 大学生の居住形態別 からみた食事状況および生活習慣状況調査, 日本食生活 学会誌, 24: 271-280, 2014.

14）中井あゆみ, 古泉佳代, 小川睦美, 吉﨑貴大, 砂見綾香, 横 山友里, 安田 純, 佐々木和登, 多田由紀, 日田安寿美, 小 久保友貴, 外山健二, 井上久美子, 川野 因 : 首都圈にお ける女子大学生の朝食欠食と健康的生活行動との関連, 日本食育学会誌, 9: 41-51, 2015.

15) Pyne DB, Hopkins WG, Batterham AM, Gleeson M, Fricker PA. Characterising the individual performance responses to mild illness in international swimmers. $\mathrm{Br}$ J Sports Med 39: 752-756, 2005.

16) Ekblom B, Ekblom O, Malm C. Infectious episodes before and after a marathon race. Scand J Med Sci Sports 16: 287-293, 2006.

17) Ferrari HG, Gobatto CA, Manchado-Gobatto FB. Training load, immune system, upper respiratory symptoms and performance in well-trained cyclists throughout a competitive season. Biol Sport 30: 289294, 2013.

18) Kostka T, Berthouze SE, Lacour J, Bonnefoy M. The symptomatology of upper respiratory tract infections and exercise in elderly people. Med Sci Sports Exerc 32: 46-51, 2000.

19) Heikkinen $T$, Jarvinen A. The common cold. Lancet 361: 51-59, 2003. 